\title{
Economic perspectives of the Blockchain technology: Application of a SWOT analysis
}

\author{
Nadezda Firsova \\ Czech University of Life Science Prague, Prague, Czech Republic \\ e-mail: firsova@pef.czu.cz \\ Josef Abrhám \\ Czech University of Life Science Prague, Prague, Czech Republic \\ e-mail:abrhamj@pef.czu.cz
}

Citation: Firsova, N., Abrhám, J. (2021). Economic perspectives of the Blockchain technology: Application of a SWOT analysis. Terra Economicus 19(1): 78-90. DOI: 10.18522/2073-66062021-19-1-78-90

Our paper focuses on the economic perspective of the Blockchain technology in economics and business in general and in agricultural business in particular. The field of the study is the European agri-food supply chain and related government politics (CAP, F2F, Green Deal) focused on the Czech Republic. Analysis of the agribusiness is conducted on an evaluating the existing data from the FADN CZ database and Eurostat database. Blockchain technology is evaluated through fundamental analysis of the context. Findings from this investigation were used in enhanced SWOT-analysis in the context of technological foresight. This method examines both the existing situation, external factors and forces, as well as possible changes in the future. Our results confirmed that Blockchain technology has big opportunities in agricultural business and agri-food supply chain in the digital economy. The group of issues that could be solved with Blockchain includes food traceability, support of new business models and direct sales models, rebalance the power in the food chain, etc. The key problem of the Czech agricultural business is inefficiency and low innovative activities. However, existing state support and positive trends show perspectives in this area. Although the Blockchain could bring benefits, there is a research gap related to financing the Blockchain implementation and cooperation between businesses and the authorities.

Keywords: Blockchain technology; agriculture; agri-food supply chain; digital economy; SWOT-analysis

JEL codes: Q1, 013, 032, G38

Acknowledgements: The paper has been supported by the Internal Grant Agency (IGA) of Faculty of Economics and Management, Czech University of Life Sciences Prague, Grant No. 2020A0016 (The Potential of Blockchain Technology in the Czech Republic in the Context of European Agricultural and Food Policies).

(c) Н. Фирсова, Й. Абрхам, 2021 


\title{
Перспективы технологии блокчейн в аграрном комплексе: SWOT-анализ
}

\author{
Надежда Фирсова \\ Чешский сельскохозяйственный университет в Праге, Прага, Чешская Республика \\ e-mail: firsova@pef.czu.cz \\ Йосеф Абрхам \\ Чешский сельскохозяйственный университет в Праге, Прага, Чешская Республика \\ e-mail:abrhamj@pef.czu.cz
}

\begin{abstract}
Цитирование: Firsova, N., Abrhám, J. (2021). Economic perspectives of the Blockchain technology: Application of a SWOT analysis. Terra Economicus 19(1): 78-90. DOI: 10.18522/20736606-2021-19-1-78-90
\end{abstract}

Наша статья посвящена перспективам технологии Blockchain в экономике и бизнесе в целом и в сельскохозяйственном бизнесе - в частности. Областью исследования является цепочка поставок в Европейском агропромышленном комплексе и связанные с ним государственные политические инициативы (CAP, F2F, Green Deal), нацеленные на контекст Чешской Республики. Анализ агробизнеса основан на оценке данных, предоставляемых в виде открытых баз данных организаций FADN CZ и Eurostat. Перспективность использования Технологии Блокчейн оценена с помощью системного анализа контекста ее использования в цепочке поставок. Результаты исследования послужили основой для расширенного SWOT-анализа технологии блокчейн и перспектив её применения. Данный метод исследует текущие экономические условия, внешние факторы и силы, а также возможные изменения в будущем. Наши результаты подтверждают, что технология блокчейн обладает большими возможностями применения в агробизнесе и цепочках поставок в агропромышленном комплексе в условиях цифровой экономики. Комплекс проблем, которые могут быть решены с помощью технологии блокчейн, включают, хотя и не ограничиваются ими, вопросы отслеживания продуктов питания и сырья, поддержки новых моделей бизнеса и модели прямых продаж, перераспределения баланса влияния в цепочке поставок. Ключевой проблемой бизнеса в этом секторе в Чешской Республике является низкая эффективность и низкий уровень инновационной активности компаний. Тем не менее, текущая государственная поддержка и положительный тренд указывают на перспективность в этой области. Блокчейн здесь может принести преимущества сектору, однако поле для исследований, связанных с оценкой целесообразности финансирования применения технологии блокчейн и ее использования при взаимодействии организаций между собой и с регулирующими органами, остается открытым.

Ключевые слова: технология блокчейн; аграрный сектор; агропромышленный комплекс; цепочка поставок; дигитализация; SWOT-анализ

Благодарность: Данная работа подготовлена в рамках гранта Внутреннего грантового агентства факультета экономики и управления Чешского сельскохозяйственного университета в Праге, грант № 2020 А0016 («Потенциал технологии блокчейн для Чешской Республики в контексте европейских сельскохозяйственных и продуктовых политик»).

\section{Introduction}

The agricultural sector is essential to achieving the strategic goals in terms of food security, rural development, environmental protection, biodiversity, sustainable development, etc. (Becvarova et al., 2005; Janda et al., 2013). Agri-food supply chain includes all participants from the input producers to the consumers, and the whole EU agri-food sector provides around 43 million jobs. Since 
the 1950s, the Common Agricultural Policy (CAP) in the European Union (EU) has been one of the priority policies. It has played an important role in the development of agri-food sector and support the competitiveness of EU producers in the world market (Mikus et al., 2019). However, agriculture is long-term characterized by a stagnant share of added value and high input costs. Moreover, the new CAP is faced higher environmental standards, rural development issues, and societal demands on food and health (Dax et al., 2018; Lisin et al., 2018; European Commission, 2019).

The current agribusiness is characterized by the demand orientation with the dominant position of food and beverage manufacture and distribution, the bargaining power asymmetries with limited power for the many individual farmers and agriculture producers, as well as asymmetric price transmission (Abrham et al., 2015; Kruja, 2020). The producers realize the direct sales only to a limited extend, thus do not use market opportunities enough (Fabregas et al., 2019; European Commission, 2019).

Agricultural business and the related agri-food supply chain are global and focused not only on product and process. The key innovative direction is related to organizational innovation, new technologies, digitalization, and interaction with consumers (Zlyvko et al., 2014; European Commission, 2019). Nowadays, the digital domain has gotten attention in connection with promises to improving the producers' efficiency, increasing labor productivity, and formation of a sustainable agribusiness. The use of data in agriculture allows firms to obtain up-to-date information for their ongoing decisionmaking (Gorshkova, Kusmartseva, 2020; Xiong et al., 2020). Although information and communication technologies are used in agriculture to collect data, most of the important data and food documentation on safety, provenance, and other attributes are typically on paper, and they are used for inspecting by trusted authorities. In this case, the access to data is related to additional transaction costs and the risk of fraud or corruption. The solve of problem transparency of information and the lack of trust in the supply chain should be realized on blockchain technology (Motta et al., 2020).

The rise of blockchain technology is associated with the cryptocurrency called "Bitcoin". This special type of decentralized distributed database was based on the principle of realization of trustworthy financial transactions without the use of a central authority (Nakamoto, 2008). Connected with the scope of the "Internet of Thing" solutions, blockchain may be implemented in many areas such as supply chain, financial and insurance market, government, tourism, health, energy, property management, energy transactions etc. (Abrham,Wang, 2017; Mistry et al., 2020; Cabelkova et al., 2020). Blockchain can reduce the information and transaction costs, support the information and financial flow in the supply chain and provides trustworthy access to the business information. Despite these benefits, there some issues that must be examined for the wide implementation of blockchain technology in agribusiness (Rejeb et al., 2020).

This paper analyzes the blockchain technology and places it in the context of European agribusiness. The remaining of this paper is organized as follows: the second part describes European agribusiness in the context of the CAP and innovation. The third part examines blockchain technology, its taxonomy, advantages, and disadvantages for agribusiness. The Results section is containing the SWOT-analysis output which is focused on the blockchain perspective in European agribusiness. The final part concludes the paper and shows the most perspective direction of blockchain implementation, as well as summarizes the current limits of the technology's implementation.

\section{European agribusiness and CAP}

The current stage of agribusiness can be examined as a system that included all activities from purchasing inputs for agricultural production, through primary production, storage, processing, distribution, and sale of finalized production to consumer (Lin et al., 2020). The stage can be characterized by the following points:

- The final demand has a critical impact on the quantity, structure, and delivery of production.

- The flow of food and agricultural products is affected by companies and organizations (including non-agricultural companies), transnational corporations, government, and authorities.

- The push for liberalization in agricultural markets.

- The demand for high value-added foods is growing; retailers determine business models in food chains. 
- Consumers are more interested in food quality, healthcare, food safety, bioterrorism, etc.

- Companies are consolidating, verticals are creating with using the economy of scale and coordination of follow-up activities.

- The competition is represented by the competition of commodity verticals in the relevant segment of the food market (Becvarova et al., 2005).

European agribusiness is characterized by bargaining power asymmetry, reduced power for individual farmers, and asymmetric price transmission along the agri-food supply chain. The lack of structural changes in agribusiness is explained by reduced mobility of production factors and limited access to capital. Nowadays, European agribusiness yields a high concentration level in processing, distribution, and retail. On the other way, important issues of farmers' cooperation lie in a lack of trust, an absence of cooperation, high competition, an unwillingness to share decision-making, cultural reasons, etc. Although agricultural production is key to the functioning of the whole chain, an alarming trend shows that the share of value-added of primary producers in the value chain generally does not exceed 25\% in the EU-28 Member States (see Fig. 1) (European Commission, 2019).

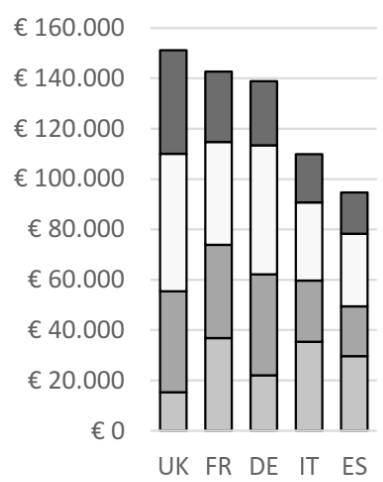

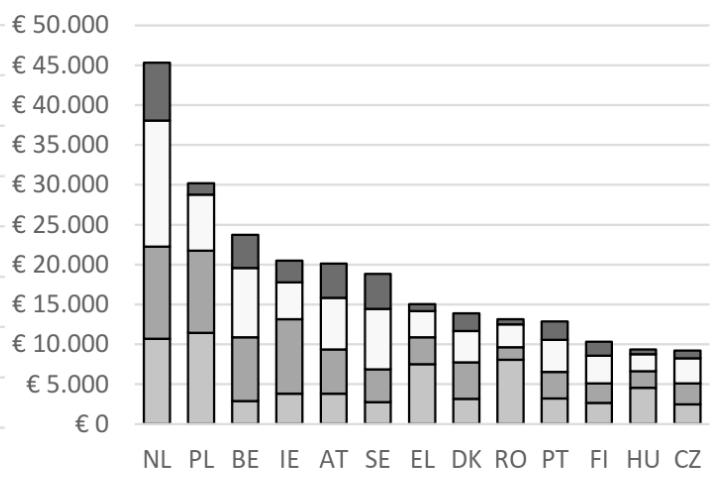

$\square$ food and baverage distribution

$\begin{array}{ll}\square \text { food and baverage consumer services } & \square \text { food and baverage } \\ \square \text { food and baverage manufactering } & \square \text { primary producers }\end{array}$

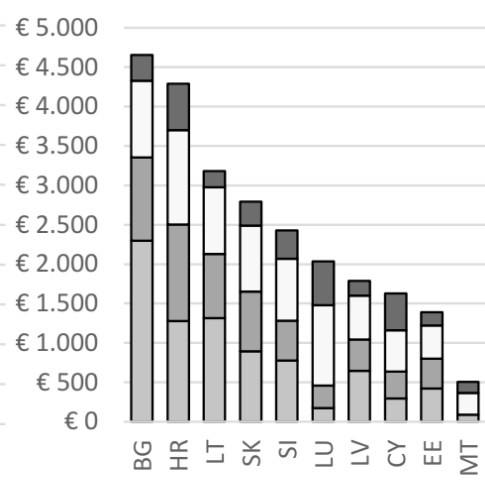

呂

Fig. 1. Value added in the food chain in million EUR in the EU Member States (EU-28) Source: DG AGRI based on Eurostat from European Commission (2019).

According to Čechura, it is necessary to examine simultaneous transmissions of market signals, shocks and the influence of other important characteristics on the relationships inside agri-food chain. Moreover, scale of food industry predetermines the scale of agriculture, its efficiency and productivity in the Czech Republic (Čechura, 2009). In the Czech Republic, technical inefficiency is an important factor for both agriculture and the food industry. The main reasons for the decline in technical efficiency in 2004-2007 were competition and the growing supply of foreign production. Another factor was the lack of capital faced by both farmers and producers (Cechura et al., 2015).

Processes in agribusiness require to supersede those regulatory instruments in agricultural policies that hinder competition. On the contrary, policies should motivate the effective restructuring of agricultural activities and the performance of other functions in the sector. CAP was launched in 1962 and has solved issues of support farmers, improve agricultural productivity, safeguard the EU market, maintain EU rural areas and landscape, keep the rural economy, etc. For the period 20212027, the CAP has built on nine key objectives: "(1) to ensure a fair income to farmers; (2) to increase competitiveness; (3) to rebalance the power in the food chain; (4) climate change action; (5) environmental care; (6) to preserve landscapes and biodiversity; (7) to support generational renewal; (8) vibrant rural areas; (9) to protect food and health quality" (European Commission, 2021a). The total allocation for the common agricultural policy amounts are separated between two funds - European agricultural guarantee fund, which provide income support schemes (basic payment scheme, a payment for sustainable farming methods, payment for young farmers, intervention buying, private storage aid, sector-specific supports, etc.), and European agricultural fund for rural development related to the EU's rural development objectives: "improving the competitiveness of agriculture, en- 
couraging sustainable management of natural resources and climate action, achieving a balanced territorial development of rural economies and communities" (European Commission, 2021).

Support for farmers under the CAP is represented by the amount of subsidy on the example of the Czech Republic (Table 1). According to CAP, a subsidies' distribution shows transfer from direct payments, e.g. SAPS, to rural development. The largest decline in direct payments is recorded for small businesses (-22,14 \% from 2014 to 2018). The aim of the environmental subsidies is the protection and improvement of the environment, landscape, and properties. These subsidies are mostly used by very large companies, which have increased the amount of support by 50\% from 2014 to 2018.

Table 1

Extended subsidies - economic size of companies (without very small companies), the EU methodology, in million CZK - the Czech Republic

\begin{tabular}{|l|c|c|c|c|c|c|}
\hline \multirow{4}{*}{ Subsidies } & \multirow{2}{*}{ Year } & \multicolumn{5}{|c|}{ Economic size } \\
\cline { 2 - 7 } & & Small & $\begin{array}{c}\text { Medium } \\
\text { low }\end{array}$ & $\begin{array}{c}\text { Medium } \\
\text { high }\end{array}$ & Large & Very large \\
\hline $\begin{array}{l}\text { Single area payment scheme (since } \\
\text { 2015 incl. Greening and Young } \\
\text { farmer) }\end{array}$ & 2018 & 838.64 & 573.06 & $1,234.44$ & $3,806.11$ & $11,555.65$ \\
\cline { 2 - 7 } & 2017 & 847.20 & 530.86 & $1,226.20$ & $3,813.16$ & $11,376.12$ \\
\cline { 2 - 7 } & 2016 & 875.83 & 694.20 & $1,230.19$ & $4,146.19$ & $11,258.19$ \\
\cline { 2 - 7 } & 2015 & 985.29 & 620.14 & $1,283.13$ & $3,934.49$ & $11,841.29$ \\
\cline { 2 - 7 } & 2014 & $1,077.12$ & 692.92 & $1,378.07$ & $4,426.12$ & $13,190.20$ \\
\hline Environmental subsidies & 2018 & 477.15 & 350.49 & 544.48 & $1,666.25$ & $2,319.73$ \\
\cline { 2 - 7 } & 2017 & 518.73 & 341.22 & 562.10 & $1,715.22$ & $2,371.02$ \\
\cline { 2 - 7 } & 2016 & 499.56 & 373.11 & 526.10 & $1,869.43$ & $1,833.36$ \\
\cline { 2 - 7 } & 2015 & 540.83 & 310.24 & 547.83 & $1,581.29$ & $1,592.78$ \\
\cline { 2 - 7 } & 2014 & 564.89 & 315.72 & 464.12 & $1,598.81$ & $1,538.62$ \\
\hline \multirow{4}{*}{$\begin{array}{l}\text { Subsidies on intermediate con- } \\
\text { sumption }\end{array}$} & 2018 & 3.03 & 0.30 & 0.16 & 1.19 & 2.83 \\
\cline { 2 - 7 } & 2017 & 2.14 & 0.50 & 0.14 & 0.48 & 2.86 \\
\cline { 2 - 7 } & 2016 & 0.44 & 0.07 & 0.84 & 0.60 & 3.30 \\
\cline { 2 - 7 } & 2015 & 9.76 & 2.57 & 4.58 & 7.10 & 12.98 \\
\cline { 2 - 7 } & 2014 & 6.45 & 2.96 & 9.89 & 15.61 & 22.70 \\
\hline Subsidies on investments & 2018 & 246.63 & 159.28 & 246.19 & 494.56 & $2,032.08$ \\
\cline { 2 - 7 } & 2017 & 162.14 & 81.39 & 129.69 & 372.47 & 1644.29 \\
\cline { 2 - 7 } & 2016 & 25.73 & 15.14 & 8.74 & 40.4 & 45.34 \\
\cline { 2 - 7 } & 2015 & 321.01 & 208.40 & 251.46 & 470.02 & 1523.04 \\
\cline { 2 - 7 } & 2014 & 35.74 & 122.29 & 90.38 & 320.38 & 765.02 \\
\hline
\end{tabular}

Source: FADN CZ, 2021.

The European Green Deal and From Farm to Fork are other important EU strategies that affect agribusiness. The Farm to Fork Strategy (F2F) is one of the key points of the Green Deal. The F2F strategy faces the challenges of sustainable food systems and recognizes the inextricable links between healthy people, healthy societies, and a healthy planet. The COVID-19 pandemic has shown the importance of a steady food system. However, F2F can be a new approach to European value food sustainability, which will benefit consumers' health and quality of life. The F2F Strategy facilitates reducing the environmental and climate footprint of the EU food system. For these purposes, the strategy focuses on specific opportunities: a neutral or positive environmental impact on the food chain, ensuring food security, generating fairer economic returns, and ensure the affordability of food. The European Agricultural Fund for Rural Development (EAFRD) and other funds will provide financial and technical support of F2F Strategy (European Commission, 2020).

According to Gorshkova and Kusmartseva (2020), there are factors that negatively affect investment in the development of agriculture. Some of those can be applied in general, such as: insuffi- 
cient capital, insufficient capital turnover, small company could not allow themselves some automation or modern technologies, seasonality of production, low labor productivity and lack of skilled workforce, small primary producers' share in the retail prices, high competitions, the risk of cyber threats, technology and infrastructure lags, low financial literacy in rural areas, high cost of Research and Development (Gorshkova, Kusmartseva, 2020).

In case of investment in information communication technologies, it is necessary to examine it in terms of innovation activities. There are two major research approaches: research on innovation generation and research on the adoption and use of innovation. The next is good to be aware of categories of innovation related on tangible (capital goods, seeds, machines) or intangible (approaches, schemes) things. These are related with the investments funds - private investors more likely to invest in tangible innovations and in intangible innovations with intellectual property right protections only (Gardner, Rausser, 2001).

Investment activity in the agricultural were analyzing using the indicator of gross fixed assets formation (Table 2). The chain indices represent dynamic of investment in new agricultural production capacities. Table 3 shows the investments in machinery and equipment in agriculture, forestry and fishing. According to Eurostat, investment in fixed assets in agriculture in the Czech Republic in 2014 decreased by 5\% and in 2015 by 16,7\%. However, investment in machinery and equipment in 2014 increased by 10,7\%. The Czech Republic has a positive dynamics of capital formation, which also includes depreciation.

Table 2

Gross fixed assets formation for Agriculture, forestry and fishing (flows), in current prices

\begin{tabular}{|c|c|c|c|c|c|c|c|c|c|c|c|c|}
\hline & \multicolumn{2}{|c|}{$\mathbf{2 0 1 3}$} & \multicolumn{2}{c|}{$\mathbf{2 0 1 4}$} & \multicolumn{2}{c|}{$\mathbf{2 0 1 5}$} & \multicolumn{2}{c|}{$\mathbf{2 0 1 6}$} & \multicolumn{2}{|c|}{$\mathbf{2 0 1 7}$} & \multicolumn{2}{|c|}{$\mathbf{2 0 1 8}$} \\
\cline { 2 - 15 } & $\begin{array}{c}\text { mil } \\
\text { EUR }\end{array}$ & $\begin{array}{c}\mathbf{2 0} \text { by } \\
\mathbf{2 0 1 2}\end{array}$ & $\begin{array}{c}\text { mil } \\
\text { EUR }\end{array}$ & $\begin{array}{c}\mathbf{\%} \text { by } \\
\mathbf{2 0 1 3}\end{array}$ & $\begin{array}{c}\text { mil } \\
\text { EUR }\end{array}$ & $\begin{array}{c}\text { \% by } \\
\mathbf{2 0 1 4}\end{array}$ & $\begin{array}{c}\text { mil } \\
\text { EUR }\end{array}$ & $\begin{array}{c}\text { \% by } \\
\mathbf{2 0 1 5}\end{array}$ & $\begin{array}{c}\text { mil } \\
\text { EUR }\end{array}$ & $\begin{array}{c}\text { \% by } \\
\mathbf{2 0 1 6}\end{array}$ & $\begin{array}{c}\text { mil } \\
\text { EUR }\end{array}$ & $\begin{array}{c}\text { \% by } \\
\mathbf{2 0 1 7}\end{array}$ \\
\hline BE & $1,141.7$ & 96.1 & $1,133.7$ & 99.3 & $1,160.6$ & 102.4 & $1,156.1$ & 99.6 & $1,233.2$ & 106.7 & $1,406.2$ & 114.0 \\
\hline CZ & $1,427.0$ & 110.0 & $1,355.0$ & 95.0 & $1,128.2$ & 83.3 & $1,455.3$ & 129.0 & $1,647.8$ & 113.2 & $1,653.1$ & 100.3 \\
\hline DE & $9,677.0$ & 98.3 & $9,708.0$ & 100.3 & $9,551.0$ & 98.4 & $9,099.0$ & 95.3 & $9,609.0$ & 105.6 & $9,889.0$ & 102.9 \\
\hline HU & 927.5 & 97.2 & $1,094.3$ & 118.0 & 941.7 & 86.1 & 854.4 & 90.7 & $1,012.9$ & 118.6 & $1,206.5$ & 119.1 \\
\hline AU & $2,363.6$ & 103.5 & $2,038.5$ & 86.2 & $2,047.5$ & 100.4 & $1,889.2$ & 92.3 & $2,175.1$ & 115.1 & $2,310.0$ & 106.2 \\
\hline PO & $3,682.0$ & 106.1 & $4,029.3$ & 109.4 & $4,666.5$ & 115.8 & $4,294.3$ & 92.0 & $4,172.9$ & 97.2 & $3,861.8$ & 92.5 \\
\hline SK & 534.2 & 97.2 & 521.5 & 97.6 & 594.6 & 114.0 & 611.7 & 102.9 & 706.0 & 115.4 & 636.2 & 90.1 \\
\hline
\end{tabular}

Source: Eurostat, 2021.

Table 3

Gross fixed assets formation - Machinery and equipment and weapons systems, for Agriculture, forestry and fishing (flows), in current prices

\begin{tabular}{|c|c|c|c|c|c|c|c|c|c|c|c|c|}
\hline & \multicolumn{2}{|c|}{2013} & \multicolumn{2}{|c|}{2014} & \multicolumn{2}{|c|}{2015} & \multicolumn{2}{|c|}{2016} & \multicolumn{2}{|c|}{2017} & \multicolumn{2}{|c|}{2018} \\
\hline & $\begin{array}{l}\text { mil } \\
\text { EUR }\end{array}$ & $\begin{array}{l}\% \text { by } \\
2012\end{array}$ & $\begin{array}{l}\text { mil } \\
\text { EUR }\end{array}$ & $\begin{array}{l}\% \text { by } \\
2013\end{array}$ & $\begin{array}{l}\text { mil } \\
\text { EUR }\end{array}$ & $\begin{array}{l}\text { \% by } \\
2014\end{array}$ & $\begin{array}{l}\text { mil } \\
\text { EUR }\end{array}$ & $\begin{array}{l}\% \text { by } \\
2015\end{array}$ & $\begin{array}{l}\text { mil } \\
\text { EUR }\end{array}$ & $\begin{array}{l}\% \text { by } \\
2016\end{array}$ & $\begin{array}{c}\text { mil } \\
\text { EUR }\end{array}$ & $\begin{array}{l}\% \text { by } \\
2017\end{array}$ \\
\hline BE & 805.2 & 95.8 & 804.9 & 100.0 & 725.2 & 90.1 & 721.4 & 99.5 & 764.2 & 105.9 & 857.1 & 112.2 \\
\hline CZ & 759.6 & 102.4 & 841.2 & 110.7 & 702.9 & 83.6 & 941.8 & 134.0 & 970.1 & 103.0 & $1,168.3$ & 120.4 \\
\hline $\mathrm{DE}$ & $6,498.0$ & 97.9 & $6,522.0$ & 100.4 & $6,464.0$ & 99.1 & $6,369.0$ & 98.5 & $6,582.0$ & 103.3 & $6,840.0$ & 103.9 \\
\hline HU & 443.6 & 105.7 & 615.3 & 138.7 & 501.5 & 81.5 & 464.1 & 92.5 & 577.5 & 124.4 & 664.9 & 115.1 \\
\hline AU & $1,285.1$ & 98.7 & $1,101.2$ & 85.7 & $1,020.5$ & 92.7 & 975.3 & 95.6 & $1,231.1$ & 126.2 & $1,303.1$ & 105.8 \\
\hline PO & $1,387.3$ & 92.5 & $1,515.2$ & 109.2 & $1,739.4$ & 114.8 & $1,592.9$ & 91.6 & $1,546.2$ & 97.1 & $1,459.8$ & 94.4 \\
\hline SK & 323.9 & 105.7 & 309.4 & 95.5 & 355.6 & 114.9 & 362.0 & 101.8 & 427.1 & 118.0 & 403.8 & 94.5 \\
\hline
\end{tabular}

Source: Eurostat, 2021. 
Changes in the business environment, business habits and consumer behavior also affect agribusiness. New trend is related to the consumer interest in local food and new business models in agri-food supply chain without intermediates (direct sales). According to European Commission, about $15 \%$ of small farms in European Union sell half or more production to customer in a direct way. It is necessary to form a partnership to improve bargaining power and for using more rural developments tools in more efficient way (European Commission, 2014).

\section{The outlook of Blockchain technology}

The term Blockchain, depending on the context, could represent a distributed peer-to-peer system with a common field of application, algorithm, data structure, or generally a computational paradigm compatible with a distributed economic system (Leng et al., 2018; Drescher, 2017). A comprehensive definition which includes a wider area of attributes and property of Blockchain is provided by Baralla et al. (2019). In this term Blockchain "is a shared and immutable data structure, which can be represented as a distributed digital ledger whose items are grouped into blocks logically connected to each other and chained in chronological order, managed by a peer-to-peer network, each containing multiple transactions, whose integrity and immutability is guaranteed by using cryptographic hash primitives. Each node within the network has a private copy of the ledger and it must agree to a consensus protocol in order to validate a new block, therefore it is not required that the involved nodes know each other identity" (Baralla et al., 2019). The important property of Blockchain is collectively managing the leger where every participant contributes to verifying a new record. In case of blockchain implementation in business, it could be defined as "ledger of accounts and transactions that are written and stored by all participants" (Xiong et al., 2020).

Blockchain could be described by its important properties. A number of researchers (e.g. Hackius, Petersen, 2017; Kouhizadeh, Sarkis, 2018) consider three important properties - decentralizing, verifying, and immutability 0ther authors expand the property list to include other ones that could help understand the point (Table 4).

\section{Blockchain technology properties}

Table 4

\begin{tabular}{|l|l|}
\hline \multicolumn{1}{|c|}{ Property } & \multicolumn{1}{c|}{ Description } \\
\hline Decentralizing & It isn't necessary the participation of a central trustworthy authority \\
\hline Verifying / Cryptography & Verification uses a public/private key cryptography \\
\hline Immutable & Added and verified transaction cannot be changed \\
\hline Transparent & $\begin{array}{l}\text { In general, each participant has access to all transactions in the database } \\
\text { (depends on the architecture of Blockchain) }\end{array}$ \\
\hline Open Source & $\begin{array}{l}\text { Blockchain code is open to everyone and every participant can create own } \\
\text { application }\end{array}$ \\
\hline Autonomy & $\begin{array}{l}\text { It is unlikely that one person can intervene the whole systems. Every time } \\
\text { the systems provides an update of transaction database with existing } \\
\text { number of participants }\end{array}$ \\
\hline Anonymity & $\begin{array}{l}\text { In general, data and transaction can be anonymous and only the public } \\
\text { key is open information for the other peers }\end{array}$ \\
\hline
\end{tabular}

Source: Hackius, Petersen (2017); Iuon-Chang Lin, Tzu-Chun Liao (2017); Kouhizadeh, Sarkis (2018); Seebacher, Schüritz (2017).

The types of Blockchain architectures can be divided into three types: (1) Public blockchain - it doesn't require any permission from any authority or validator, everyone can participate the consensus process. The most known public Blockchain solution are cryptocurrency (Bitcoin, Ethereum, etc.). (2) Consortium blockchain (also federated) has predetermined role of authority who has known for the other participants. If the data are open or private depended on rules conditions of the 
Blockchain consortium network. This type of architecture is often used in business partnership and the famous platform is the Hyperledger. (3) Private blockchain - the closest type of network, the roles are predetermined, and the participants are usually restricted. The owner of private Blockchain provides the access and regulate all process in the network (Ge et al., 2017; Iuon-Chang Lin, TzuChun Liao, 2017; Kamilaris et al., 2019; Kouhizadeh, Sarkis, 2018).

The second classification of Blockchain is based on a consensus algorithm, i.e. how the new transaction block can be added to the database. "Proof of Work" is the most popular algorithm which is used in cryptocurrency. However, it is associated with high computing power and, hence, with the energy costs. An alternative algorithm is called "Proof of Stake" where different peers have a different approving power according to their stakes in the network (Cole et al., 2019; Kamilaris et al., 2019).

Smart contract is one of the Blockchain application in business environment. It allows to transform terms and conditions of the physical contract into digital copy (algorithms and code) and implement it exactly by the rules. For instance, the Letter of Credit could be the conditions of trade operation which can be controlled automatically. Nowadays, smart contracts are often realized on the Ethereum platform and in general have a high processing speed and high security level (Belu, 2019).

One of the important characteristics of Blockchain technology that have a significant importance for the agricultural and food challenges, is trust. The base of Blockchain "promises a reliable source of truth" - for the assets, inventories, contracts or other points. And the next important thing, that it could help in communications between producers and consumers (Xiong et al., 2020).

Like any technical solution, Blockchain has weaknesses, most of which lie in technical limits: (1) The Majority Attack (51\% Attacks) - if a participant controls 51\% of peers in the Blockchain then he/she can control the whole Blockchain. Probably this situation could be occurring in case, then someone joins other peers to the "pools" and collects the computer power. (2) Fork problem is related to the software upgrade (and separating networks by the nodes) and can occur in a wide range of public blockchain. Participants face the problem of new agreement and transfer to the new network. (3) Problem of Scale - because of growing Blockchain, in a public network it is need for more and more power and store to synchronize the data. (4) Time Confirmation - even in Blockchain a transaction is not approved immediately (it needs about 1 hour). (5) Current Regulation Problems the power of cryptocurrencies as a speculative and financial instrument is growing and it could have a negative impact on the world financial systems. For instance, between December 2020 and March 2021, bitcoin grew twice to $€ 36,000$. (6) Integrated Cost Problem is related to hidden costs (infrastructure, time, knowledge). The main point is that new technology should create benefits and minimalize the negative impacts on traditional business process (Iuon-Chang Lin,Tzu-Chun Liao, 2017).

In contrast, the advantages of Blockchain include: (1) Thanks to disintermediation the system is able to work without any central data storage or expensive infrastructure in one hands. The costs are redistributed among the network. (2) High quality of transaction data. (3) Cyber-attack durability. (4) Fast money or property management transactions. (5) Reducing transaction costs by eliminating intermediaries and overhead costs. (6) Efficiency document management. (7) Creating self-describing smart contracts with existing applications. (8) Traceability, tracking goods (Niranjanamurthy et al., 2019).

The study of peer-review articles shows a number of potential Blockchain implication that are directly related to agribusiness and the agri-food supply chain (e.g. Baralla et al., 2019; Sylvester, 2019; Kamilaris et al., 2019). A number of review studies collect the most frequent ways of using Blockchain in the research area. Some studies focus on creating the conceptual model to ensure food safety with managing privacy and risk. Moreover, some papers propose a Blockchain system that works with IoT and RFID technologies. The evolution of the Blockchain propose was in direction of food traceability and provenance. It can be related to ensuring the ethnicity of typical products or products with come predefined characteristics (organic food, Fair Trade, etc.). Smart contracts could manage risk in the supply chain, also concerning frauds and cybercrimes. The next Blockchain designs try to solve the problem of using both the public network like storage for the open data and the second private for the sensible data. Systems like this represent a more complicated architecture that proposed models with a large number of participants with different roles to the circular 
economy. Finally, new proposals have occurred which implement the Farm to Fork scenario with more complicated transaction logic.

\section{Methodological framework}

The methodological framework of the present study is based on a systematic analysis of Blockchain technology which is evaluated through a fundamental analysis of the context. Conclusions are drawn from the analysis of available professional sources based on analytical-synthetic procedures. Analysis of the agribusiness was conducted on an evaluating the existing data from the FADN CZ database and Eurostat database. Findings from these analyses were used in enhanced SWOT-analysis (SWOT is an acronym for strengths, weaknesses, opportunities, and threats which represents a structured planning method) in the context of technological foresight.

Proposed by Nazarko et al. (2017), an extension of classic SWOT-analysis contains an additional dimension of time. As a result, the classic four-field SWOT-matrix was redesigned in eight-field matrix. The new approach reflects such the new criteria: occurrence in time (existing or potential), source of origin (from inside of the system or from the environment), nature of influence (favourable or unfavourable). The new characteristics are:

- "Strengths - most importantly, existing at the time of analysis, the properties of the system: active or inactive but it is possible to be activate.

- Weaknesses - most importantly, existing at the time of analysis, system properties, which are brakes or barriers to its development.

- Internal opportunities - opportunities with great potential, distinctive tested system, stemming from its internal structure.

- Internal threats - most importantly, the existing (but for now inactive) properties of analysed system, which are the brakes of its development internal-system situations with high probability of losing the asset extension.

- Stimulants - active external factors contributing to the development of the system.

- Disincentives - active external factors that are barriers or brakes of system development.

- External opportunities - the most important current and potential positive external factors.

- External threats - most negative external factors, the occurrence of which in the projection horizon is highly likely" (Nazarko et al., 2017).

\section{SWOT analysis framework}

Table 5 presents the characteristics of the Blockchain as well as the existing and potential effects of the external environment. It is obvious from the analysis, that favorable inside factors are representing the existing properties of the Blockchain technology. This view shows the current state of technology development. The Stimulants (existing favorable external factors) consists of some external activities with a current positive impact on the adoption of technology. For instance, a big interest in cryptocurrency from the big companies can improve the image of Bitcoin and Blockchain, as well as emergency of digital currency in the EU. Politics in the agri-food supply chain have more common ideas that could be realized in Blockchain. Automation and digitalization also have positive impact on Blockchain adoption. The weaknesses are mostly represented by current disadvantages of Blockchain. The disincentive group consists of the speculative investor behavior, bad reputation of cryptocurrencies cybercriminals, etc. Nowadays, it is very important to consider the government restriction because of COVID-19 and their impact on global economy. Future internal opportunities include potential positive developments in the technology and business models based on Blockchain. Customer experience with emerging Blockchain application will be able to build the communication ant interactive base to create more efficiency application for the new business models. External future opportunities are based on the digitalization of economy and society. Potential internal threats conduct the possible lack of security (in case of emerge quantum computing) and a common uncertainly of the future way of research. External threats include negative trends in economics, government regulation and the possibility of having the new intermediates in the supply chain. 
Table 5

The extended SWOT matrix

\begin{tabular}{|c|c|c|c|}
\hline & Inside the system & Outside the system & \\
\hline $\begin{array}{l}\frac{0}{0} \\
\frac{\pi}{\pi} \\
\frac{0}{\pi} \\
\frac{\pi}{4}\end{array}$ & $\begin{array}{l}\text { Strength } \\
\text { Transparency. } \\
\text { Traceability. } \\
\text { Do not need the intermediary. } \\
\text { Cheap entry to systems. } \\
\text { Anonymity. } \\
\text { Security. } \\
\text { Robustness. } \\
\text { Trust. } \\
\text { Open Source }\end{array}$ & $\begin{array}{l}\text { Stimulants } \\
\text { Investors behavior. } \\
\text { Digital national currencies. } \\
\text { CAP, Green Deal, F2F. } \\
\text { Automation. } \\
\text { IoT, Industry } 4.0\end{array}$ & \multirow{2}{*}{ 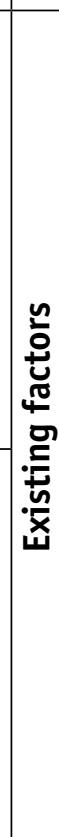 } \\
\hline 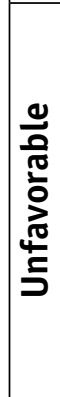 & $\begin{array}{l}\text { Weakness } \\
\text { Storage space. } \\
\text { The lack of regulation (Legacy). } \\
\text { High variable costs. } \\
\text { Fork problem. } \\
\text { Many application and standards. } \\
\text { Low processing speed. } \\
\text { Scalability }\end{array}$ & $\begin{array}{l}\text { Disincentives } \\
\text { Investors behavior (speculative). } \\
\text { Bad reputation in business } \\
\text { environment. } \\
\text { Money laundering and illegal financial } \\
\text { flows. } \\
\text { Cybercriminal. } \\
\text { COVID restrictions, recession. } \\
\text { Hype }\end{array}$ & \\
\hline 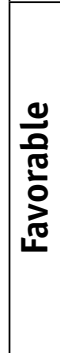 & $\begin{array}{l}\text { Internal opportunities } \\
\text { Technology maturity. } \\
\text { Support of emerging new business models. } \\
\text { Improve business process efficiency. } \\
\text { Trust in more trustless networks. } \\
\text { Customer experience. } \\
\text { New versions of smart contracts }\end{array}$ & $\begin{array}{l}\text { External opportunities } \\
\text { Changing in global monetary systems } \\
\text { (adoption). } \\
\text { Government regulation. } \\
\text { Automation. } \\
\text { Customer experience. } \\
\text { Increase the digitalization part of } \\
\text { human live }\end{array}$ & \multirow{2}{*}{ 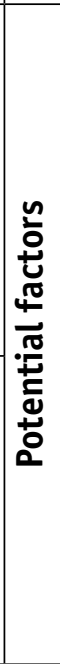 } \\
\hline 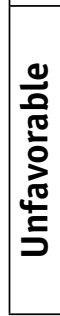 & $\begin{array}{l}\text { Internal threats } \\
\text { The lack of security (quantum computing). } \\
\text { Uncertainly of the future research (inside) }\end{array}$ & \begin{tabular}{|l|} 
External threats \\
Uncertainly of future research (outside). \\
Government regulation. \\
Cybercriminal. \\
New intermediates. \\
Strengthening the regulation of \\
economics
\end{tabular} & \\
\hline
\end{tabular}

Source: 0wn research.

\section{Conclusions and implications}

Our original research analyzed the current state of Blockchain technology in the context of agribusiness in EU and showed the potential way of Blockchain implementation in the agri-food supply chain. The key direction of possible implementation lies in a realization strategy From Farm to Fork and the Green Deal. The properties and advantages of Blockchain could help to create a workable system for food traceability and provenance. The new CAP also includes topics related to reducing intermediaries (direct sales), increasing competitiveness, rebalance the power in the food chain, and protecting food and health quality. All these issues could examine in the Blockchain model's development.

An existing research gap is related to financing the agribusiness digitalization in common and financing the Blockchain projects. The system of subsidies in CAP and the state subsidies should provide the necessary level of financial support. The researches show technical inefficiency in Czech agricultural and food-processing companies. Support of innovation activities and know-how should spread firstly in less productive regions. 
The extended SWOT analysis describe the existing and potential factors related to Blockchain technology. The results show that existing factors contain the currently Blockchain property and current situation in the financial and investment markets. Foresights of the Blockchain development show opportunities and threats that could emerge in the nearest future. The main positive direction will be able to relate with the adoption of cryptocurrencies, new business models, and customers' experience with Blockchain applications. The negative impact will be in the case of quantum computing or government restrictions.

The future of Blockchain technology in agribusiness is connected with cooperation between state and business, investment activities, and implementing the new business models. Moreover, Blockchain is not a mature technology and is still has a lot of technical issues and development gaps.

\section{Литература / References}

Abrham, J., Strielkowski, W., Vošta, M., Šlajs, J. (2015). Factors that influence the competitiveness of Czech rural SMEs. Agricultural Economics 61(10): 450-460. doi: 10.17221/63/2015-AGRICECON

Abrham, J., Wang, J. (2017). Novel trends on using ICTs in the modern tourism industry. Czech Journal of Social Sciences, Business and Economics 6(1): 37-43. doi: 10.24984/cjssbe.2017.6.1.5

Baralla, G., Pinna, A., Corrias, G. (2019). Ensure traceability in European food supply chain by using a Blockchain system, s. 40-47. In: 2019 IEEE/ACM 2nd International Workshop on Emerging Trends in Software Engineering for Blockchain (WETSEB): 2019 IEEE/ACM 2nd International Workshop on Emerging Trends in Software Engineering for Blockchain (WETSEB). Montreal, QC, Canada: IEEE. doi: 10.1109/WETSEB.2019.00012

Becvarova, V. (2005). The Essence and Economic Context of the Formation of Agribusiness. Brno: Mendel University of Agriculture and Forestry.

Belu, M. (2019). Application of Blockchain in international trade: An overview. The Romanian Economic Journal XXII(7): 2-16.

Cabelkova, I., Strielkowski, W., Wende, F.D., Krayneva, R. (2020). Factors influencing the threats for urban energy networks: The inhabitants' point of view. Energies 13(21): 5659. doi: 10.3390/en13215659

Cechura, L., Hockmann, H., Malý, M., Žáková Kroupová, Z. (2015). Comparison of technology and technical efficiency in cereal production among EU countries. Agris on-line Papers in Economics and Informatics, 7(665-2016-45054), 27-37. doi: 10.7160/aol.2015.070203

Čechura, L. (2009). Sources and limits of growth of the agricultural sector: analysis of efficiency and productivity of the Czech agricultural sector - application SFA (Stochastic Frontier Analysis). Prague: Wolters Kluwer Czech Republic.

Cole, R., Stevenson, M., Aitken, J. (2019). Blockchain technology: Implications for operations and supply chain management. Supply Chain Management: An International Journal 24(4): 469-483. doi: 10.1108/SCM-09-2018-0309

Dax,T.,Fischer,M.(2018).Analternativepolicyapproachtoruraldevelopmentinregionsfacingpopulation decline. European Planning Studies 26(2), 297-315. doi: 10.1080/09654313.2017.1361596

Drescher, D. (2017). Blockchain Basics: A Non-Technical Introduction in 25 Steps. Berkeley, CA: Apress.

European Commission (2014). Guidelines on programming for innovation and the implementation of the EIP for agriculture productivity and sustainability. Programming period 2014-2020. December (https://ec.europa.eu/eip/agriculture/sites/agri-eip/files/eip-guidelines-july-2014_en.pdf).

European Commission (2019). CAP specific objectives. Brief No. 3. Farmer position in value chains (https://ec.europa.eu/info/sites/info/files/food-farming-fisheries/key_policies/documents/ cap-specific-objectives-brief-3-farmer-position-in-value-chains_en.pdf).

European Commission (2020). A Farm to Fork Strategy for a fair, healthy and environmentally-friendly food system. 20 May 2020. (https://ec.europa.eu/info/sites/info/files/communication-annexfarm-fork-green-deal_en.pdf). 
European Commission (2021). Common agricultural policy funds (https://ec.europa.eu/info/foodfarming-fisheries/key-policies/common-agricultural-policy/financing-cap/cap-funds_en).

Fabregas, R., Kremer, M., Schilbach, F. (2019). Realizing the potential of digital development: The case of agricultural advice. Science 366(6471). doi:10.1126/science.aay3038

Gardner, B.L., Rausser, G.C. (eds.) (2001). Handbook of Agricultural Economics. Amsterdam; New York: Elsevier. Handbooks in economics.

Ge, L., Brewster, C., Spek, J., Smeenk, A., Top, J., Diepen, F. van, Klaase, B., Graumans, C., Ruyter de Wildt, M. de. (2017). Blockchain for agriculture and food: Findings from the pilot study. Wageningen Economic Research report, no. 2017-112. doi: 10.18174/426747

Gorshkova, N.V., Kusmartseva, N.V. (2020). Financial Aspects of the Digital Economy Development in the Agricultural Sector, s. 164-172. In: A.0. Inshakova, N.I. Inshakova (eds.) Competitive Russia: Foresight Model of Economic and Legal Development in the Digital Age. Cham: Springer International Publishing, Lecture Notes in Networks and Systems. doi:10.1007/978-3-03045913-0_19

Hackius, N., Petersen, M. (2017). Blockchain in logistics and supply chain: trick or treat? Digitalization in Supply Chain Management and Logistics: Smart and Digital Solutions for an Industry 4.0 Environment. Proceedings of the Hamburg International Conference of Logistics (HICL) 23: 3-18. doi:10.15480/882.1444

Iuon-Chang, L., Tzu-Chun, L. (2017). A survey of Blockchain security issues and challenges. International Journal of Network Security 19(5): 653-659. doi:10.6633/IJNS.201709.19(5).01

Janda, K., Rausser, G., Strielkowski, W. (2013). Determinants of profitability of Polish rural microenterprises at the time of EU Accession. Eastern European Countryside 19(1): 177-217. doi: 10.2478/eec-2013-0009

Kamilaris, A., Fonts, A., Prenafeta-Boldy, F.X. (2019). The rise of blockchain technology in agriculture and food supply chains. Trends in Food Science \& Technology [online] 91: 640-652. doi:10.1016/j. tifs.2019.07.034

Kouhizadeh, M., Sarkis, J. (2018). Blockchain practices, potentials, and perspectives in greening supply chains. Sustainability 10(10): 3652. doi: 10.3390/su10103652

Kumar, V.M., Iyengar, N.Ch.S.N. (2017). A Framework for Blockchain Technology in Rice Supply Chain Management Plantation, s. 125-130. In: Future Generation Communication and Networking 2017. doi:10.14257/astl.2017.146.22

Lin, J., Li, L., Luo, X.R., Benitez, J. (2020). How do agribusinesses thrive through complexity? The pivotal role of e-commerce capability and business agility. Decision Support Systems 135: 113342. doi: $10.1016 / j$.dss.2020.113342

Lisin, E., Shuvalova, D., Volkova, I., Strielkowski, W. (2018). Sustainable development of regional power systems and the consumption of electric energy. Sustainability 10(4): 1111. doi: 10.3390/ su10041111

Leng, K., Bi, Y., Jing, L., Fu, H.-C., Van Nieuwenhuyse, I. (2018). Research on agricultural supply chain system with double chain architecture based on Blockchain technology. Future Generation Computer Systems 86: 641-649. doi: 10.1016/j.future.2018.04.061

Lucena, P., Binotto, A.P.D., Momo, F.S., Kim, H. (2018). A case study for grain quality assurance tracking based on a Blockchain business network. arXiv:1803.07877 (http://arxiv.org/abs/1803.07877).

Mikus, 0., Kukoc, M., Rogelj, M.J. (2019). The coherence of common policies of the EU in territorial cohesion: A never-ending discourse? A review. Agricultural Economics 65(3): 143-149. doi: 10.17221/229/2018-AGRICECON

Mistry, I., Tanwar, S., Tyagi, S., Kumar, N. (2020). Blockchain for 5G-enabled IoT for industrial automation: A systematic review, solutions, and challenges. Mechanical Systems and Signal Processing, 135: 106382. doi: 10.1016/j.ymssp.2019.106382 
Motta, G.A., Tekinerdogan, B., Athanasiadis, I.N. (2020). Blockchain applications in the agri-food domain: The first wave. Frontiers in Blockchain 3. doi:10.3389/fbloc.2020.00006

Nakamoto, S. (2008). Bitcoin: A peer-to-peer electronic system (https://bitcoin.org/bitcoin.pdf).

Nazarko, J., Ejdys, J., Halicka, K., Magruk, A., Nazarko, L., Skorek, A. (2017). Application of Enhanced SWOT Analysis in the Future-oriented Public Management of Technology. Procedia Engineering 182: 482-490. doi:10.1016/j.proeng.2017.03.140

Niranjanamurthy, M., Nithya, B.N., Jagannatha, S. (2019). Analysis of Blockchain technology: Pros, cons and SWOT. Cluster Computing 22(S6): 14743-14757. doi:10.1007/s10586-018-2387-5

Rejeb, A., Keogh, J.G., Zailani, S., Treiblmaier, H., Rejeb, K. (2020). Blockchain technology in the food industry: A review of potentials, challenges and future research directions. Logistics 4(4): 27. doi: https://doi.org/10.3390/logistics4040027

Seebacher, S., Schüritz, R. (2017). Blockchain technology as an enabler of service systems: A structured literature review. In: S. Za, M. Drăgoicea, M. Cavallari (eds.) Exploring Services Science. IESS 2017. Lecture Notes in Business Information Processing 279. Springer.

Sylvester, G. (ed.) (2019). E-agriculture in action: Blockchain for agriculture: Opportunities and challenges. Bangkok: Food and Agriculture Organization of the United Nations and International Telecommunication Union.

Xiong, H., Dalhaus, T., Wang, P., Huang, J. (2020). Blockchain technology for agriculture: Applications and rationale. Front. Blockchain 3: 7. doi:10.3389/fbloc.2020.00007

Zlyvko, 0., Lisin, E., Rogalev, N., Kurdiukova, G. (2014). Analysis of the concept of industrial technology platform development in Russia and in the EU. International Economics Letters 3(4): 24-138. doi: 10.24984/iel.2014.3.4.2 